\title{
Mycoplasma muris, a New Species from Laboratory Mice
}

\author{
G. J. MCGARRITY, ${ }^{1 *}$ D. L. ROSE, ${ }^{2}$ V. KWIATKOWSKI, ${ }^{1}$ A. S. DION, ${ }^{1}$ D. M. PHILLIPS, ${ }^{3}$ AND J. G. \\ TULLY ${ }^{2}$
}

Institute for Medical Research. Camden, New Jersey $08103^{1}$; Mycoplasma Section, Laboratory of Molecular Microbiology, National Institute of Allergy and Infectious Diseases, Frederick, Maryland 20701 ; and Population Council, Rockefeller University, New York, New York ${ }^{3}$

\begin{abstract}
Three mycoplasma strains were isolated from the vaginal tracts of strain RIII mice. These isolates had similar biochemical and serological properties and grew on SP-4 medium but not on conventional mycoplasma medium containing horse serum and yeast extract. Anaerobic incubation was required. These organisms hydrolyzed arginine but not urea, produced a film and spot reaction, and were susceptible to $1.5 \%$ digitonin. Cholesterol was required for growth, and the organisms adsorbed to guinea pig erythrocytes and exhibited uridine phosphorylase activity. The organisms were serologically distinct from 82 Mycoplasma species and unclassified serotypes. On the basis of these findings and other morphological and biological properties of the organisms, we propose that mycoplasma strains with these characteristics belong to a new species, Mycoplasma muris. Strain RIII-4 (= ATCC 33757) is the type strain.
\end{abstract}

The Mycoplasma flora of laboratory rodents consists primarily of strains of Mycoplasma arthritidis, Mycoplasma pulmonis, and Mycoplasma neurolyticum. Each of these organisms has been shown to occur latently in mice or rats and to be associated with an economically important natural disease in laboratory rodents under appropriate conditions of stress (2). Although these three Mycoplasma species occur most frequently in rodents, several other mycoplasmas have been recovered from mice and rats. Hill (4) reported the isolation of two serologically similar strains from the conjunctiva of a rat (strain 58B) and the nasopharynx of a mouse (strain Gough). However, these organisms have not been characterized further. In addition, mycoplasmas have been recovered from the intestinal contents of mice (R. N. Gourlay and S. Wyld, Proc. Soc. Gen. Microbiol. 3:142, 1976). These organisms preferred an anaerobic environment for growth, fermented glucose, and were serologically distinct from other murine mycoplasmas. These strains have not been examined further to establish their relationships to other mycoplasmas.

As new culture media for mycoplasmas are described and examinations of a variety of laboratory rodents maintained under selective microbial barriers are performed, new mycoplasmas may be recovered. The purpose of this paper is to report the isolation of a new species of Mycoplasma from mouse strain RIII. The mycoplasmas characterized here were recovered only in the specialized culture medium (SP4) that was originally used in the isolation of helical mycoplasmas (spiroplasmas) (17). These organisms were also selective in other growth requirements, since growth regularly occurred only under anaerobic conditions.

\section{MATERIALS AND METHODS}

Culture media, sampling, and cultivation procedure. Vaginal samples were obtained from mouse strains RIII and C57BL/6 by using nasopharyngeal swabs (Falcon Plastics, Oxnard, Calif.). Sampling included both pregnant and nonpregnant females. The swabs were inoculated into the following mycoplasma agar and broth media: conventional agar and broth, formulated as described previously (9); U-10B agar and broth, which have been described previously for ureaplasmas (14); and SP-4 agar and broth, which are used for spiroplasmas (17). Specimens were inoculated into test media containing $500 \mathrm{U}$ of penicillin per $\mathrm{ml}$ and $100 \mu \mathrm{g}$ of streptomycin per $\mathrm{ml}$. Four sets of each medium were inoculated, and broth and agar media were incubated under both aerobic and anaerobic conditions at 30 and $37^{\circ} \mathrm{C}$. Anaerobic conditions were established by using the GasPak system (BBL Microbiology Systems, Cockeysville, Md.). Subcultures were made from broth to agar after 7 and 14 days of incubation. Plates were read at least weekly under $\times 100$ magnification.

After primary isolation, three mycoplasmas (which were all recovered from SP-4 broth maintained anaerobically at $37^{\circ} \mathrm{C}$ ) were adapted to grow on conventional mycoplasma broth medium containing $20 \%$ fetal bovine serum. Most of the subsequent test procedures for further characterization were performed with one of these isolates (strain RIII-4 ${ }^{\mathrm{T}}$ [type strain]) adapted to the broth medium containing fetal bovine serum. Agar plates prepared with either SP-4 medium or the conventional broth containing fetal bovine serum contained 0.8\% Noble agar (Difco Laboratories, Detroit, Mich.).

The two mycoplasma media which supported growth of the mouse isolates were also used to study 
possible reversion of the strains to bacteria. Early passages of the isolates were grown on media devoid of penicillin and other antibiotics for at least five consecutive passages. At each subculture, the broth cultures were also plated onto blood agar plates. These plates were then incubated at $37^{\circ} \mathrm{C}$ under both anaerobic and aerobic conditions for 4 to 5 days and examined for bacterial colonies.

Animals. Inbred colonies of strain RIII and C57BL/6 mice have been maintained at the Institute for Medical Research under environmental control for the past 14 years, and these colonies have been used in studies on murine mammary tumor virus. The mice used in this study ranged in age from 3 to 10 months and included pregnant and nonpregnant females. Strains RIII and C57BL/6 are maintained in separate rooms in the animal facility.

Morphological studies. Broth cultures of the organisms were examined by dark-field microscopy, especially after anaerobic incubation at $37^{\circ} \mathrm{C}$ for 4 to 5 days. Cellular morphology was also examined after Gram staining and observation by light microscopy. Ultra-structural examinations were performed with pellets of broth-propagated organisms that were harvested by centrifugation at $15,000 \mathrm{rpm}$ for $30 \mathrm{~min}$ in a Beckman type 30 rotor head, fixed in $2 \%$ glutaraldehyde, and prepared for electron microscopy as previously described (11).

Filtration studies. A 4-day broth culture of strain RIII-4 ${ }^{\mathrm{T}}$ was grown anaerobically and examined for passage of cells through a series of membrane filters with graded pore diameters $(450,300,220$, and $100 \mathrm{~nm})$ by using techniques described previously (15). Agar plates seeded with serial dilutions of each filtrate were incubated anaerobically, and the number of colonies on each plate was recorded after 14 days.

Tests for biological and biochemical properties. The procedures used to assess glucose fermentation, arginine hydrolysis, urea hydrolysis, phosphatase activity, tetrazolium reduction, liquefaction of coagulated serum, and film and spot production have been described previously $(1,18)$. All procedures were performed with broth or agar cultures that were grown anaerobically for 4 to 7 days. Susceptibility to digitonin was assayed by using a plate method and mycoplasma agar containing $20 \%$ fetal bovine serum (3). Adsorption of guinea pig erythrocytes to agar colonies of the isolates was tested by a previously described technique (7).

Sterol requirement. Growth responses to cholesterol were determined by using a technique that was modified slightly from the recommended direct broth method (12). We prepared a series of 11 flasks of medium (conventional mycoplasma broth base formulation, but devoid of serum or cholesterol) supplemented with $10 \%$ fresh yeast extract, $1 \%$ glucose, $0.25 \%$ arginine, and $0.002 \%$ phenol red. This base medium was added to each flask, and various supplements (albumin, fatty acids, cholesterol, serum) were incorporated to give the final concentrations shown in Table 1. Each medium preparation was then distributed into a series of eight small vials $(1.8 \mathrm{ml} / \mathrm{vial})$. The first vial in each series was inoculated with $0.2 \mathrm{ml}$ of a broth culture of the test strain (strain RIII-4 $4^{\mathrm{T}}$, and serial 10-fold dilutions were made up to a $10^{-8}$ dilution. The inoculum was prepared from a culture grown anaerobically for 4 days in the mycoplasma broth containing $20 \%$ fetal
TABLE 1. Sterol requirement test for strain RIII-4 ${ }^{\mathrm{T}}$

\begin{tabular}{lccc}
\hline $\begin{array}{c}\text { Addition to } \\
\text { base medium }\end{array}$ & Concn & \multicolumn{2}{c}{$\begin{array}{c}\text { No. of color-changing } \\
\text { units/ml after } \\
\text { anaerobic incubation } \\
\text { at } 37^{\circ} \mathrm{C} \text { for: }\end{array}$} \\
\cline { 2 - 4 } & & $10^{1}$ & $10^{1}$ \\
None $^{a}$ & & $10^{1}$ & $10^{1}$ \\
None $^{b}$ & & $10^{2}$ & $10^{2}$ \\
Cholesterol $^{c}$ & $1.0 \mu \mathrm{g} / \mathrm{ml}$ & $10^{1}$ & $10^{1}$ \\
& $5.0 \mu \mathrm{g} / \mathrm{ml}$ & $10^{1}$ & $10^{1}$ \\
& $10 \mu \mathrm{g} / \mathrm{ml}$ & 0 & $10^{1}$ \\
& $20 \mu \mathrm{g} / \mathrm{ml}$ & $10^{1}$ & $10^{1}$ \\
Fetal bovine & $0.5 \%$ & $10^{2}$ & $10^{2}$ \\
serum $^{c}$ & $5.0 \%$ & $10^{2}$ & $10^{3}$ \\
& $10 \%$ & $10^{4}$ & $10^{5}$ \\
& $15 \%$ & $10^{6}$ & $10^{6}$ \\
\hline
\end{tabular}

a Serum-free base medium alone.

${ }^{b}$ Base medium supplemented with $0.5 \%$ albumin, $0.01 \%$ Tween 80 , and $10 \mu \mathrm{g}$ of palmitic acid per $\mathrm{ml}$.

All medium preparations contained $0.5 \%$ albumin, $0.01 \%$ Tween 80 , and $10 \mu \mathrm{g}$ of palmitic acid per $\mathrm{ml}$.

bovine serum. The 11 series of vials were placed in the GasPak system, the caps were loosened to allow oxygen removal, and the vials were incubated anaerobically at $37^{\circ} \mathrm{C}$ for 14 and 21 days. Endpoints of growth were determined by examining vials for turbidity and an alkaline shift in the $\mathrm{pH}$ indicator in the broth. The last tube showing these changes was recorded as the number of color-changing units of growth per milliliter.

Serological tests. For serological tests, hyperimmune antisera to 82 reference mycoplasmas were prepared. These reference mycoplasmas were obtained from the National Institutes of Health Research Reference Reagent (NIH) or from the Mycoplasma Section, Laboratory of Molecular Microbiology, National Institute of Allergy and Infectious Diseases (MS). The strains used were Mycoplasma agalactiae PG2 ${ }^{\mathrm{T}}$ (obtained from NIH), Mycoplasma alkalescens DBS-803 (MS), Mycoplasma alvi Ilsley ${ }^{\mathrm{T}}$ (MS), Mycoplasma anatis $1340^{\mathrm{T}}$ (NIH), Mycoplasma arginini $\mathrm{G} 230^{\mathrm{T}}$ (NIH), M. arthritidis PG6 ${ }^{\mathbf{T}}(\mathrm{NIH})$, Mycoplasma bovigenitalium PG11 ${ }^{\mathrm{T}}$ (NIH), Mycoplasma bovirhinis PG43 ${ }^{\mathrm{T}}$ (NIH), Mycoplasma bovis Donetta ${ }^{\mathrm{T}}$ (MS), Mycoplasma bovoculi M165/69 ${ }^{\mathrm{T}}$ (MS), Mycoplasma buccale CH20247. (NIH), Mycoplasma californicum ST-6 ${ }^{\mathrm{T}}$ (MS), Mycoplasma canadense $275 \mathrm{C}^{\mathrm{T}}$ (MS), Mycoplasma canis PG14 ${ }^{\mathrm{T}}$ (NIH), Mycoplasma capricolum California kid $^{\mathrm{T}}$ (MS), Mycoplasma caviae $\mathrm{G} 122^{\mathrm{T}}$ (MS), Mycoplasma citelli RG-2C $\mathrm{C}^{\mathrm{T}}$ (MS), Mycoplasma columbinsale $694^{\mathrm{T}}$ (MS), Mycoplasma columbinum MMP1 ${ }^{\mathrm{T}}$ (MS), Mycoplasma columborale MMP4 ${ }^{\mathrm{T}}$ (MS), Mycoplasma conjunctivae HRC581 ${ }^{\mathrm{T}}$ (MS), Mycoplasma cynos $\mathrm{H} 831^{\mathrm{T}}$ (MS), Mycoplasma dispar $462 / 2^{\mathrm{T}}$ (MS), Mycoplasma edwardii PG24 ${ }^{\mathrm{T}}$ (MS), Mycoplasma equigenitalium $\mathrm{T} 37^{\mathrm{T}}$ (MS), Mycoplasma equirhinis $\mathrm{M} 432 / 72^{\mathrm{T}}$ (MS), Mycoplasma fastidiosum $4822^{\mathrm{T}}$ (MS), Mycoplasma faucium DC333 ${ }^{\mathrm{T}}$ (NIH), Mycoplasma feliminutum Ben ${ }^{\mathrm{T}}$ (MS), Mycoplasma felis Cat 27 (MS), Mycoplasma fermentans PG18 ${ }^{\mathrm{T}}$ (NIH), Mycoplasma flocculare $\mathrm{Ms}^{\mathrm{T}} \mathrm{T}^{\mathrm{T}}$ (MS), Mycoplasma gallinaceum SA-J (MS), Mycoplasma gallinarum PG16 ${ }^{T}$ 
(NIH), Mycoplasma gallisepticum $\mathrm{PG} 31^{\mathrm{T}}$ (NIH), $M y-$ coplasma gallopavonis WR1 ${ }^{\mathrm{T}}$ (MS), Mycoplasma gatae Mart (MS), Mycoplasma hominis PG21 T (NIH). Mycoplasma hyopneamoniae $\mathrm{J}^{\mathrm{T}}$ (MS), Mycoplasma hyorhinis BTS7 ${ }^{\mathrm{T}}$ (NIH), Mycoplasma hyosynoviae $\mathrm{S}^{\mathrm{T}}$ (MS), Mycoplasma iners PG30 ${ }^{\mathrm{T}}$ (NIH), Mycoplasma iowae $695^{\mathrm{T}}$ (MS), Mycoplasma lipophilum $\mathrm{MaBy}^{\mathrm{T}}$ (NIH), Mycoplasma maculosum PG15 (NIH), Mycoplasma meleagridis $17529^{\mathrm{T}}$ (NIH), Mycoplasma moatsii MK405 ${ }^{\mathrm{T}}$ (MS), Mycoplasma molare H542 ${ }^{\mathrm{T}}$ (MS), Mycoplasma mycoides subsp. mycoides B3 (MS), Mycoplasma mycoides subsp. capri $\mathrm{PG}^{\mathrm{T}}$ (MS), $M$. nearolyticum type $\mathrm{A}^{\mathrm{T}}$ (NIH), Mycoplasma opalescens MH5408 ${ }^{\mathrm{T}}$ (MS), Mycoplasma orale $\mathrm{CH} 19299^{\mathrm{T}}$ (NIH), Mycoplasma ovipneumoniae $\mathrm{Y}^{\mathrm{N}} 8^{\mathrm{T}}$ (MS), Mycoplasma pneamoniae $\mathrm{FH}^{\mathrm{T}}$ (NIH), Mycoplasma primatum $\mathrm{HRC} 292^{\mathrm{T}}$ (MS), Mycoplasma pullorum $\mathrm{CKK}^{\mathrm{T}}$ (MS), $M$. pulmonis $\mathrm{PG} 34^{\mathrm{T}}$ (NIH), Mycoplasma patrefaciens $\mathrm{KS}-1^{\mathrm{T}}$ (MS), Mycoplasma salivarium $\mathrm{PG} 20^{\mathrm{T}}$ (NIH), Mycoplasma spumans $\mathrm{PG}^{\mathrm{T}}{ }^{\mathrm{T}}$ (NIH), Mycoplasma sualvi Mayfield B ${ }^{\mathrm{T}}$ (MS), Mycoplasma subdolum $\mathrm{TB}^{\mathrm{T}}$ (MS), Mycoplasma synoviae WVU1853 $3^{\mathrm{T}}$ (MS). Mycoplasma verecundam $107^{\mathrm{T}}$ (MS), Mycoplasma sp. strain primate B-291 (MS), Mvcoplasma sp. strain bovine California calf (MS), Mycoplasma sp. strain bovine group 7 BSP (MS), Mycoplasma sp. strain 70-159 (MS), Mycoplasma sp. strain caprine G145 (MS), Mycoplasma sp. strain mouse Gough (MS), Acholeplasma axanthum H86N (MS), Acholeplasma equifetale N93 (MS), Acholeplasma granularum BTS39 ${ }^{\mathrm{T}}$ (NIH), Acholeplasma hippikon $\mathrm{C}^{\mathrm{T}}$ (MS), Acholeplasma laidlawii $\mathrm{PG}^{\mathrm{T}}$ (NIH), Acholeplasma modicum PG49 ${ }^{\mathrm{T}}$ (MS), Acholeplasma morum $72-043^{\mathrm{T}}$ (MS), Acholeplasma oculi $19 \mathrm{~L}^{\mathrm{T}}$ (MS), Spiroplasma citri $\mathrm{Maroc}^{\mathrm{T}}$ (MS), Spiroplasma mirum $\mathrm{SMCA}^{\mathrm{T}}$ (MS), and Spiroplasma $\mathrm{sp}$. strain corn stunt E-275 (MS).

Disk growth inhibition tests were performed with two isolates (strains RIII-4 ${ }^{\mathrm{T}}$ and RIII-8) that were grown anaerobically for 5 days in SP-4 broth medium or in the broth containing $20 \%$ fetal bovine serum. Antigens, which were usually used directly from broth or diluted 1:50 in uninoculated culture medium, were tested against undiluted antiserum. The antigens were seeded onto agar plates, and the plates were incubated anaerobically for 5 to 7 days at $37^{\circ} \mathrm{C}$. The sizes of zones of growth inhibition around disks saturated with antiserum were recorded in millimeters. Growth inhibition antisera against $M$. agalactiae and $M$. synoriae were not available.

The plate immunofluorescence antibody test was performed by a direct method, using mycoplasmas grown anaerobically on agar plates. The colonies were treated with appropriate dilutions (usually $1: 15$ to $1: 30$ ) of fluorescein-conjugated antisera to the mycoplasma strains listed above.

Isolation of mycoplasma DNA and determination of base composition. To isolate mycoplasma deoxyribonucleic acid (DNA) and determine its base composition, a 7-day broth culture of strain RIII-4 ${ }^{\mathrm{T}}$ was used. For control purposes, a 2-day culture of A. laidlawii strain MG (= ATCC 29804) and a 1-day culture of Escherichia coli strain AMC (= ATCC 128) were included in this part of the study. The three organisms were coded and processed blindly in the DNA preparations. The cells from approximately $750 \mathrm{ml}$ of culture medium of each organism were collected by centrifu- gation at $15,000 \mathrm{rpm}$ for $30 \mathrm{~min}$ in a Beckman type 30 rotor head, and the resulting pellets were washed three times in phosphate-buffered saline (pH 7.2).

The cell pellets were suspended in $0.01 \mathrm{M}$ tris(hydroxymethyl)aminomethane hydrochloride $(\mathrm{pH} 8.0)$ containing $0.01 \mathrm{M}$ ethylenediaminetetraacetate and $0.01 \mathrm{M} \mathrm{NaCl}$ (TNE). Proteinase K (E. Merck, AG. Darmstadt. West Germany) and sodium dodecyl sulfate were added to final concentrations of $1 \mathrm{mg} / \mathrm{ml}$ and $0.5 \%(\mathrm{wt} / \mathrm{wt})$, respectively, and the resulting preparations were digested for 24 to $48 \mathrm{~h}$ at $37^{\circ} \mathrm{C}$. The sodium dodecyl sulfate concentration was then adjusted to $1 \%$, and the cells were extracted twice with phenol buffered with TNE.

Nucleic acids were precipitated from the aqueous phases by adding 0.1 volume of $\mathrm{NaCl}$ and 2 volumes of ethanol and placing the suspensions at $-20^{\circ} \mathrm{C}$. Precipitates were collected by centrifugation (Sorvall HS4 rotor; $3,000 \mathrm{rpm}, 30 \mathrm{~min}$ ), washed with $5 \mathrm{ml}$ of $70 \%$ ethanol buffered with TNE, and centrifuged. The final precipitates were dried in a stream of nitrogen, suspended in $3 \mathrm{ml}$ of $0.01 \mathrm{M}$ tris(hydroxmethyl)aminomethane hydrochloride $(\mathrm{pH} 7.4)$ containing $0.01 \mathrm{M}$ ethylenediaminetetraacetate and $50 \mu \mathrm{g}$ of pancreatic ribonuclease (deoxyribonuclease-free) per $\mathrm{ml}$, and digested overnight at $37^{\circ} \mathrm{C}$. Each preparation was extracted twice with phenol and then dialyzed against $0.015 \mathrm{M} \mathrm{NaCl}-0.0015 \mathrm{M}$ sodium citrate for 3 days at $4^{\circ} \mathrm{C}$.

A $500-\mu \mathrm{g}$ portion of each DNA base preparation was transferred to a hydrolysis ampoule and lyophilized to dryness. Each preparation was then suspended in $\mathbf{5 0 0}$ $\mu \mathrm{l}$ of $88 \%$ formic acid, flushed with nitrogen, and heat sealed. After hydrolysis at $175^{\circ} \mathrm{C}$ for $30 \mathrm{~min}$, the tubes were cooled to room temperature and placed on ice, and the $\mathrm{CO}_{2}$ gas was gently released. The contents of each tube were then taken to dryness in a stream of $\mathrm{N}_{2}$. The resulting residues were suspended in small volumes of $1 \mathrm{~N} \mathrm{HCl}$, and the samples were spotted onto Avicel thin-layer chromatography plates $(10$ by $20 \mathrm{~cm}$; Analtech, Newark, Del.). The bases were then separated by using the isopropanol- $\mathrm{HCl}$ solvent system $116.7 \mathrm{ml}$ of $12 \mathrm{~N} \mathrm{HCl}$ was added to $65 \mathrm{ml}$ of isopropanol, and the preparation was mixed well and made up to a final volume of $100 \mathrm{ml}$ with distilled water). After thin-layer chromatography, the plates were dried in an airstream in a fume hood, and the blue fluorescence associated with protonated guanine was converted to quenching at $260 \mathrm{~nm}$ by exposure to ammonia vapor. For quantitation, each base was eluted separately from the scraped absorbent with $0.1 \mathrm{~N}$ $\mathrm{HCl}$. The supernatants were monitored by using ultraviolet light, and the values were corrected for ultraviolet-absorbing material eluted from corresponding blank areas.

The technique of Marmur and Doty has been used to determine the guanine-plus-cytosine $(G+C)$ contents of mycoplasma DNAs (8). However, Marmur and Doty recommended the use of melting profiles for DNAs with $\mathrm{G}+\mathrm{C}$ contents of 30 to $75 \mathrm{~mol} \%$; melts tend to underestimate $\mathrm{G}+\mathrm{C}$ contents of less than 30 mol\% (8). By contrast, $\mathrm{CsCl}$ gradient analysis tends to overestimate $\mathrm{G}+\mathrm{C}$ contents (13).

Uridine phosphorylase. A 7-day broth culture of strain RIII-4 ${ }^{\mathrm{T}}$ was centrifuged at $15,000 \mathrm{rpm}$ for $30 \mathrm{~min}$ in a Beckman type 30 rotor head. The resulting cell pellet was suspended in phosphate-buffered saline $(\mathrm{pH}$ 

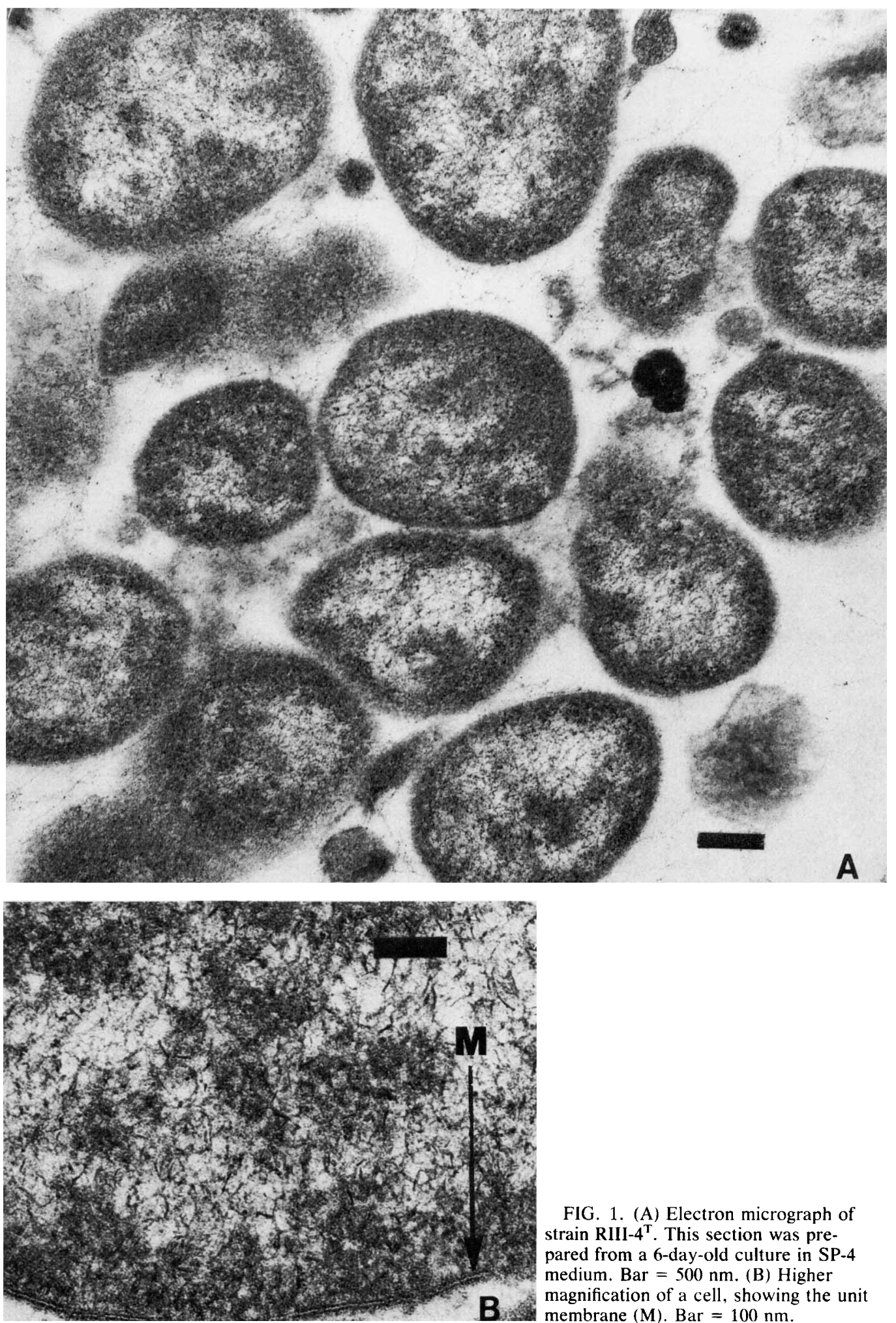

FIG. 1. (A) Electron micrograph of strain RIII-4 ${ }^{\mathrm{T}}$. This section was prepared from a 6-day-old culture in SP-4 medium. Bar $=500 \mathrm{~nm}$. (B) Higher magnification of a cell, showing the unit membrane $(M)$. Bar $=100 \mathrm{~nm}$. 
TABLE 2. Base contents of $M$. muris RIII-4 ${ }^{\mathrm{T}}, A$. laidlawii $\mathrm{MG}$, and $E$. coli AMC DNAs

\begin{tabular}{|c|c|c|c|c|c|c|}
\hline \multirow{2}{*}{ Source of DNA } & \multirow{2}{*}{ Expt } & \multicolumn{5}{|c|}{ Base content $(\mathrm{mol} \%)$} \\
\hline & & Adenine & Thymine & Guanine & Cytosine & $\mathrm{G}+\mathrm{C}$ \\
\hline \multirow[t]{4}{*}{ A. laidlawii $\mathrm{MG}$} & 1 & 32.8 & 32.6 & 17.6 & 17.1 & 34.7 \\
\hline & 2 & 32.0 & 31.5 & 18.3 & 18.2 & 36.5 \\
\hline & 3 & 32.7 & 30.9 & 18.5 & 17.9 & 36.4 \\
\hline & $\operatorname{Mean}^{a}$ & 32.5 & 31.6 & 18.1 & 17.7 & 35.8 \\
\hline \multirow[t]{4}{*}{ E. coli AMC } & 1 & 25.9 & 24.5 & 24.2 & 25.4 & 49.6 \\
\hline & 2 & 24.3 & 26.5 & 24.3 & 24.9 & 49.2 \\
\hline & 3 & 27.2 & 22.7 & 24.1 & 26.0 & 50.1 \\
\hline & $\operatorname{Mean}^{a}$ & 25.8 & 24.6 & 24.2 & 25.4 & 49.6 \\
\hline \multirow[t]{4}{*}{ M. muris RIII- $4^{\mathrm{T}}$} & 1 & 37.3 & 37.8 & 13.1 & 11.7 & 24.8 \\
\hline & 2 & 40.6 & 36.7 & 11.9 & 10.8 & 22.7 \\
\hline & 3 & 38.2 & 34.5 & 14.4 & 12.9 & 27.3 \\
\hline & Mean $^{a}$ & 38.7 & 36.3 & 13.1 & 11.8 & 24.9 \\
\hline
\end{tabular}

"Arithmetic mean.

2) and assayed for uridine phosphorylase activity by using the method of Levine and Becker (6). The criterion used for a positive reaction was as follows: more than $50 \%$ conversion of $\left[{ }^{14} \mathrm{C}\right]$ uridine to $\left[{ }^{14} \mathrm{C}\right]$ uracil in $30 \mathrm{~min}$ or an increase in conversion of $10 \%$ or more between 30 and $180 \mathrm{~min}$ of incubation.

\section{RESULTS}

Isolation of mycoplasmas. Vaginal samples were obtained from 42 female strain RIII mice ( 21 were pregnant) and 32 female strain C $57 \mathrm{BL} / 6$ mice ( 20 were pregnant). Three isolates were obtained, all from pregnant strain RIII mice. These three isolates, which were designated RIII-1, RIII-4 $4^{\mathrm{T}}$, and RIII-8, grew only on SP-4 medium at $37^{\circ} \mathrm{C}$ and only under anaerobic conditions. The recovery of these mycoplasmas from strain RIII mice did not appear to be chance isolations, since a repeat sampling of the individual mouse that yielded strain RIII- $4^{\mathrm{T}} 6$ weeks after the primary culture was obtained also yielded a mycoplasma with the same characteristics. This female was also pregnant at the time of the second isolation. Colonies of the organisms were first detected after incubation of broth cultures for 14 days at $37^{\circ} \mathrm{C}$. Each isolate was purified by standard filtration and cloning techniques, and strain RIII-4 ${ }^{\mathrm{T}}$ was selected for further characterization.

Morphology and cultural properties. Broth cultures of strain RIII-4 ${ }^{\mathrm{T}}$ examined by dark-field microscopy contained numerous pleomorphic, round or coccobacillary forms. Preparations stained by the Gram technique revealed gramnegative pleomorphic structures similar to those observed in dark-field microscopy preparations. An examination of thin sections of cell pellets by electron microscopy confirmed the frequent occurrence of oval cells, which generally were about $300 \mathrm{~nm}$ in diameter (Fig. 1). No cell wall material was apparent outside the unit membrane of the organism.

Broth cultures of strain RIII- $4^{\mathrm{T}}$ in SP-4 medium were slightly turbid after 5 days of incubation under anaerobic conditions. Approximately the same amount of growth occurred when this organism was cultivated in the broth containing $20 \%$ fetal bovine serum. Although a few classical "fried-egg" colonies were observed, most growth on SP-4 agar plates after 7 days of incubation in the GasPak system consisted of granular colonies. The colonies were generally small, averaging 50 to $100 \mu \mathrm{m}$ in diameter. No growth occurred in broth or on agar plates when cultures were incubated aerobically.

Reversion studies. Cultures of mycoplasmas maintained in antibiotic-free SP-4 broth for at least five passages exhibited growth characteristics similar to those observed when penicillin was present. There was no evidence of reversion to bacterial forms when the organisms were plated onto bacteriological agar.

Filtration studies. A cloned broth culture of strain RIII-4 ${ }^{\mathrm{T}}$ contained $1.9 \times 10^{6}$ colony-forming units per $\mathrm{ml}$ before filtration through a series of membrane filters. After filtration through membrane filters with average pore diameters of $450,300,220$, and $100 \mathrm{~nm}$, preparations contained $2.0 \times 10^{3}, 1.3 \times 10^{3}, 5.8 \times 10^{2}$, and 0 colony-forming units per $\mathrm{ml}$, respectively.

Biochemical and biological properties. Various biochemical tests were performed on strain RIII$4^{\mathrm{T}}$, and other biological properties were also determined. The characteristics of this strain are as follows: does not ferment glucose; hydrolyzes arginine but not urea; phosphatase negative; produces film and spot reactions; reduces tetrazolium anaerobically; exhibits uridine phosphorylase activity ( $91.5 \%$ conversion in $180 \mathrm{~min}$ ); shows strong hemadsorption of guinea pig eryth- 
rocytes; does not liquefy coagulated serum; susceptible to $1.5 \%$ digitonin (zone of inhibition, 9 $\mathrm{mm}$ ); requires sterol; light culture turbidity; colonies on agar are small and granular, with a few fried-egg types; anaerobic atmosphere preferred $\left(\mathrm{H}_{2}\right.$ containing $\left.5 \% \mathrm{CO}_{2}\right)$; preferred growth temperature is $37^{\circ} \mathrm{C}$.

Sterol requirement. The growth responses of strain RIII-4 ${ }^{\mathrm{T}}$ to cholesterol and fetal bovine serum are shown in Table 1 . Little growth was apparent in the base broth medium without additives, in broth containing various levels of cholesterol, or when small concentrations $(0.5$ to $5 \%$ ) of fetal bovine serum were added. Significant growth occurred only when 10 to $20 \%$ fetal bovine serum was added to the base medium. thus confirming the requirement for serum.

Serological tests. Growth inhibition and plate immunofluorescence tests, which were performed with antisera or conjugates prepared to the mycoplasmas listed above, indicated that the strain RIII isolates are not serologically related to previously described Mycoplasma species.

DNA base composition. The results of a thinlayer chromatographic analysis of DNA extracted from strain RIII- $4^{\mathrm{T}}$ indicated that this strain has a $\mathrm{G}+\mathrm{C}$ content of $24.9 \pm 1.0 \mathrm{~mol} \%$ (Table 2). Control preparations of strains of $A$. laidlaw $i i$ and $E$. coli showed $\mathrm{G}+\mathrm{C}$ contents of 35.8 and $49.6 \mathrm{~mol} \%$, respectively. These values are consistent with previously published data $(5,10)$.

\section{DISCUSSION}

Our study indicates that the mouse isolates recovered on SP-4 medium are serologically distinct from other members of species, subspecies, or unclassified serotypes of the order $M y$ coplasmatales. The growth requirements of these isolates for sterol and their cellular morphology place them in the family Mycoplasmataceae. The inability to hydrolyze urea indicates that these organisms should be assigned to the genus Mycoplasma. We believe that these organisms represent a new species within this genus and, therefore, propose the name Mycoplasma muris (mur' is. L. n. mus mouse; L. gen. n. muris of a mouse). Strain RIII-4 is the type strain. A cloned line of this strain has been deposited in the American Type Culture Collection under the number ATCC 33757.

At present, insufficient information is available to relate the new mycoplasmas to any pathological state, nor is it certain that these strains occur only in strain RIII mice or only in pregnant animals. Further isolation attempts, in which we are using the cultural and atmospheric conditions used successfully to recover the $M$. muris strains from strain RIII mice, are in progress.

\section{ACKNOWLEDGMENT}

This work was supported by Public Health Service grant AI15748 from the National Institute of Allergy and Infectious Diseases.

\section{LITERATURE CITED}

1. Aluotto, B. B., R. G. Wittler, C. O. Williamson, and J. E. Faber. 1970. Standardized bacteriologic techniques for the characterization of Mycoplasma species. Int. J. Syst. Bacteriol. 20:35-58.

2. Casell, G. H., and A. Hill. 1979. Murine and other small animal mycoplasmas, p. 235-274. In J. G. Tully and R. F. Whitcomb (ed.). The mycoplasmas, vol, 2. Human and animal mycoplasmas. Academic Press, Inc., New York.

3. Freundt, E. A., B. E. Andrews, H. Erno, M. Kunze, and F. T. Black. 1973. The sensitivity of Mycoplasmatales to sodium polyanetholsulfonate and digitonin. Zentralbl. Bakteriol. Parasitenkd. Infektionskr. Hyg. Abt. 1 Orig. 225:104-112.

4. Hill, A. 1974. Experimental and natural infection of the conjunctiva of rats. Lab. Anim. 8:305-310.

5. Hill, L. R. 1966. An index to deoxyribonucleic acid base compositions of bacterial species. J. Gen. Microbiol. 44:419-437.

6. Levine, E. M., and B. G. Becker. 1978. Biochemical methods for detecting mycoplasma contamination, p. 87-104. In G. J. McGarrity. D. G. Murphy, and W. W. Nichols (ed.). Mycoplasma infection of cell cultures. Plenum Press. New York.

7. Manchee, R. J., and D. Taylor-Robinson. 1968. Haemadsorption and hemagglutination by mycoplasmas. J. Gen. Microbiol. 50:465-478.

8. Marmur, J., and P. Doty. 1962. Determination of the base composition of deoxyribonucleic acid from its thermal denaturation temperature. J. Mol. Biol. 5:109-118.

9. McGarrity, G. J., J. Sarama, and V. Vanaman. 1979. Factors influencing microbiological detection of mycoplasmas in cell cultures. In Vitro 15:73-81.

10. Niemark, H. 1967. Heterogeneity among the mycoplasma and relationships to bacteria. Ann. N.Y. Acad. Sci. 143:31-37.

11. Phillips, D. M. 1978. Detection of mycoplasma contamination of cell cultures by electron microscopy, p. 105-118. In G. J. McGarrity, D. G. Murphy, and W. W. Nichols (ed.), Mycoplasma infection of cell cultures. Plenum Press. New York.

12. Razin, S., and J. G. Tully. 1970. Growth requirement of mycoplasmas. J. Bacteriol. 102:306-310.

13. Schildkraut, C. L., J. Marmur, and P. Doty. 1962. Determination of the base composition of deoxyribonucleic acid from its buoyant density. J. Mol. Biol. 4:430-443.

14. Shepard, M. C., and C. D. Lunceford. 1978. Serological typing of Ureaplasma urealyticum isolates from urethritis patients by an agar growth inhibition method. J. Clin. Microbiol. 8:556-574.

15. Tully, J. G., M. F. Barile, R. A. Del Giudice, T. R. Carski, D. Armstrong, and S. Razin. 1970. Proposal for classifying PG-24 and related canine mycoplasmas as Mýcoplasma edwardii sp. n. J. Bacteriol. 101:346-349.

16. Tully, J. G., M. F. Barile, D. G. ff. Edward, T. S. Theodore, and H. Erno. 1974. Characterization of some caprine mycoplasmas, with proposals for new species. Mycoplasma capricolum and Mycoplasma putrefaciens. J. Gen. Microbiol. 85:102-120.

17. Tully, J. G., R. F. Whitcomb, and H F. Clark. 1976. Pathogenic mycoplasmas: cultivation and vertebrate pathogenicity of a new spiroplasma. Science 195:893-894.

18. Williams, C. O., and R. G. Wittler. 1971. Hydrolysis and phosphatase production by members of the order $M y^{\prime} O-$ plasmatales which do not require sterol. Int. J. Syst. Bacteriol. 21:73-77. 